\title{
Clinical, functional and radiographic outcomes of primary total hip arthroplasty between direct anterior approach and posterior approach: a systematic review and meta-analysis
}

Linbo Peng ${ }^{1,2}$, Yi Zeng ${ }^{1,2}$, Yuangang $W_{u^{1,2}}$, Junfeng Zeng ${ }^{1,2}$, Yuan Liu ${ }^{1,2}$ and Bin Shen ${ }^{1,2^{*}}$ (i)

\begin{abstract}
Background: The purpose of this systematic review and meta-analysis was to compare the direct anterior approach and posterior approach for primary total hip arthroplasty in terms of the clinical, functional and radiographic outcomes.
\end{abstract}

Methods: We searched the PubMed and EMBASE databases and Cochrane Library from their inception to November 1, 2019. We searched for previously published articles and meta-analyses of randomized controlled trials.

Results: A total of 7 randomized controlled trials with 600 participants met the inclusion criteria. Among these patients, 301 and 299 were included in the DAA and PA groups, respectively. The DAA was associated with a longer surgery by a mean duration of $13.74 \mathrm{~min}\left(95 \% \mathrm{Cl} 6.88\right.$ to $20.61, p<0.0001, \mathrm{I}^{2}=93 \%$ ). The postoperative early functional outcomes were significantly better in the DAA group than in the PA group, such as the Visual Analogue Scale (VAS) score at 1 day postoperatively (MD $=-0.65,95 \% \mathrm{Cl}-0.91$ to $\left.-0.38, p<0.00001,1^{2}=0 \%\right)$, VAS score at 2 days postoperatively (MD $=-0.67,95 \% \mathrm{Cl}-1.34$ to $\left.-0.01, p=0.05, \mathrm{I}^{2}=88 \%\right)$ and Harris Hip Score (HHS) at 6 weeks postoperatively (MD $=6.05,95 \% \mathrm{Cl} 1.14$ to $\left.10.95, p=0.02, \mathrm{I}^{2}=52 \%\right)$. There was no significant difference between the DAA and PA groups in the length of the incision, hospital length of stay (LOS), blood loss, transfusion rates or complication rates. We found no significant difference between the two groups regarding late functional outcomes, such as the VAS score at 12 months postoperatively or the HHS scores at 3, 6, and 12 months postoperatively. A significant difference in the radiographic outcomes was not detected.

\footnotetext{
* Correspondence: shenbin 1971@163.com

'Department of Orthopaedic Surgery, West China Hospital, West China Medical School, Sichuan University, Chengdu, Sichuan Province 610041, People's Republic of China

2Department of Orthopedics, West China Hospital, Sichuan University, 37\#

Guoxue Road, Chengdu 610041, People's Republic of China
}

C The Author(s). 2020 Open Access This article is licensed under a Creative Commons Attribution 4.0 International License, which permits use, sharing, adaptation, distribution and reproduction in any medium or format, as long as you give appropriate credit to the original author(s) and the source, provide a link to the Creative Commons licence, and indicate if changes were made. The images or other third party material in this article are included in the article's Creative Commons licence, unless indicated otherwise in a credit line to the material. If material is not included in the article's Creative Commons licence and your intended use is not permitted by statutory regulation or exceeds the permitted use, you will need to obtain permission directly from the copyright holder. To view a copy of this licence, visit http://creativecommons.org/licenses/by/4.0/. The Creative Commons Public Domain Dedication waiver (http://creativecommons.org/publicdomain/zero/1.0/) applies to the data made available in this article, unless otherwise stated in a credit line to the data. 
(Continued from previous page)

Conclusions: The DAA requires a longer surgery time than does the PA in primary total hip arthroplasty. The DAA yields better early functional recovery than does the PA. There was no significant difference between the two groups in terms of other clinical, complication-related, late functional or radiographic outcomes. The evidence on the superiority of the DAA is insufficient and needs to be studied further.

Keywords: Total hip arthroplasty, Surgical approach, Direct anterior approach, Posterior approach, Early functional recovery

\section{Background}

With the aging of society, the morbidity of knee and hip osteoarthritis is increasing rapidly, causing a large social and economic burden [1, 2]. Total hip arthroplasty (THA) is the gold standard treatment for end-stage OA [3]. THA surgery has greatly improved the functional status of patients over the last half-century [4].

Many surgical approaches are used in THA surgery, but there is little evidence indicating which approach has the most advantages $[5,6]$. On the one hand, the direct anterior approach (DAA) is considered a true minimally invasive approach because it leads to a small amount of muscle damage, as the operation is performed through a small incision and a muscle interval in the hip joint $[7,8]$. On the other hand, the conventional posterior approach (PA) is the most frequently used surgical approach for THA [9].

Some studies show that compared with the PA, the DAA leads to less blood loss, low transfusion rates, shorter surgery times, a shorter length of hospital stay (LOS), low postoperative complication rates and better functional recovery [10-17]. Other studies have shown that DAA is associated with higher postoperative complication rates than is PA $[18,19]$, especially regarding neuropraxia in the lateral cutaneous nerve of the thigh $[18,20]$. Several metaanalyses have been published, but their results are not enough to be convincing. Retrospective studies and nonrandomized controlled trials are included in most of the meta-analyses, which leads to indirect evidence [21-23]. Nonstandard approaches such as piriformis preserving approaches and those involving computer-aided technology were inappropriately regarded as standard approaches in some studies [21-25], which should be strictly avoided for accurate results. Therefore, we performed a meta-analysis with strict inclusion criteria and includes the most recently published RCTs to compare the direct anterior approach and posterior approach for primary total hip arthroplasty in terms of the clinical, functional and radiographic outcomes.

\section{Methods}

\section{Search strategies}

We performed this study in accordance with the Cochrane Handbook for Systematic Reviews of
Interventions [26] and Preferred Reporting Items for Systematic Reviews and Meta-Analyses (PRISMA) guidelines [27]. We searched the PubMed and EMBASE databases and Cochrane Library from their inception to November 1, 2019. We searched for previously published articles and meta-analyses of randomized controlled trials. We used the keywords "Arthroplasty, Replacement, Hip" and "approach" to identify published RCTs, and we did not use any language restrictions.

The following electronic search strategy was used for PubMed: $(((()(((($ randomized controlled trial [pt]) OR controlled clinical trial [pt]) OR randomized [tiab]) OR placebo [tiab]) OR clinical trials as topic [mesh: noexp]) OR randomly [tiab]) OR trial [ti])) NOT ((animals [mh] NOT humans [mh])))) AND ((approach [Title/Abstract])

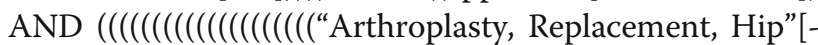
Mesh]) OR Arthroplasties, Replacement, Hip [Title/Abstract]) OR Arthroplasty, Hip Replacement [Title/ Abstract]) OR Hip Prosthesis Implantation [Title/Abstract]) OR Hip Prosthesis Implantations [Title/Abstract]) OR Implantation, Hip Prosthesis [Title/ Abstract]) OR Implantations, Hip Prosthesis [Title/Abstract]) OR Prosthesis Implantation, Hip [Title/Abstract]) OR Prosthesis Implantations, Hip [Title/ Abstract]) OR Hip Replacement Arthroplasty [Title/Abstract]) OR Replacement Arthroplasties, Hip [Title/Abstract]) OR Replacement Arthroplasty, Hip [Title/ Abstract]) OR Arthroplasties, Hip Replacement [Title/ Abstract]) OR Hip Replacement Arthroplasties [Title/ Abstract]) OR Hip Replacement, Total [Title/Abstract]) OR Replacement, Total Hip [Title/Abstract]) OR Hip Replacements, Total [Title/Abstract]) OR Replacements, Total Hip [Title/Abstract]) OR Total Hip Replacements [Title/Abstract]) OR Total Hip Replacement [Title/ Abstract])).

\section{Eligibility criteria}

(1) Participants: patients undergoing primary THA;

(2) Interventions: the intervention group underwent THA surgery with the DAA;

(3) Comparisons: the control group underwent THA surgery with the PA; 
(4) Outcomes: clinical outcomes such as the length of the incision, surgery time, length of hospital stay, blood loss, and transfusion rates; complications such as dislocation, fracture, LCNT neuropraxia, DVT and overall complications; radiographic outcomes such as acetabular inclination and acetabular anteversion; functional outcomes such as the VAS score at 1 day, 2 days, and 12 months postoperatively and the Harris hip score at 6 weeks, 3 months, 6 months, and 12 months postoperatively.

(5) Study design: randomized controlled trials.

\section{Study selection}

We imported all the studies identified in the search into Endnote X7 software (Thompson Reuters, CA, USA). Two reviewers (LBP and JFZ) scanned the titles and abstracts independently, and we resolved any disagreements by discussion with senior reviewers. RCTs comparing the DAA and PA in THA surgery were eligible for inclusion. Duplicates were removed, and we also excluded commentaries, letters, case studies and reviews. Nonstandard approaches such as piriformispreserving approaches, those involving computer-aided technology, or other surgical approaches were also excluded. Then, we read the full texts to exclude other ineligible studies.

\section{Data extraction}

Two authors extracted the following information and then reviewed the information together to guarantee the data were accurate: the name of the first author, publication year, study design, number of surgeons, number of cases in each group, follow-up duration, sex distribution, average age, BMI, learning cases, length of the incision, surgery duration, length of hospital stay, blood loss and transfusion rates, dislocation, fracture, LCNT neuropraxia, DVT and overall complication, acetabular inclination and acetabular anteversion, the VAS score at 1 day, 2 days, and 12 months postoperatively and the Harris hip score at 6 weeks, 3 months, 6 months, and 12 months postoperatively.

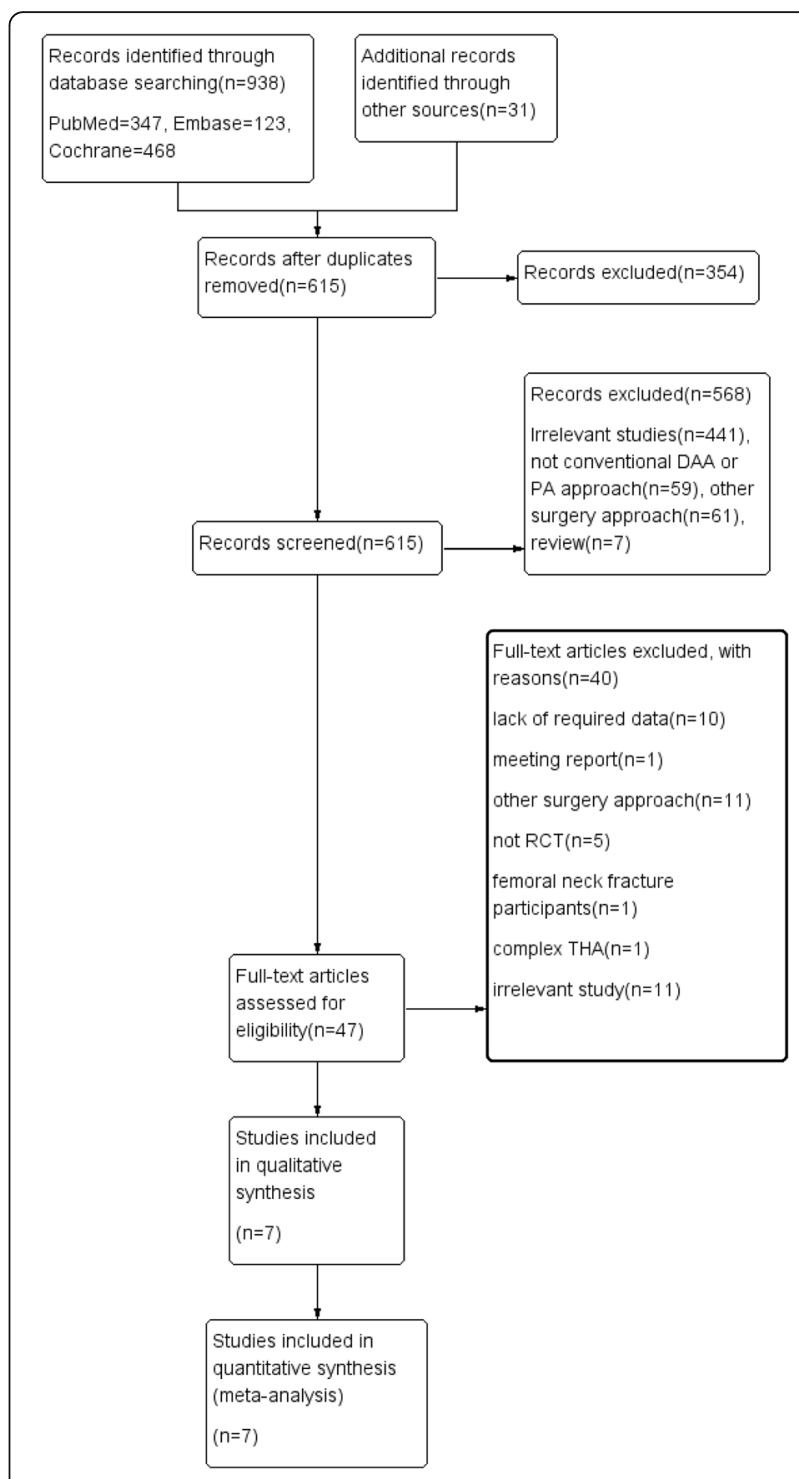

Fig. 1 PRISMA study flow diagram

Table 1 Demographic characteristics of patients

\begin{tabular}{llllllllll}
\hline Study & Year & $\begin{array}{l}\text { Study } \\
\text { design }\end{array}$ & $\begin{array}{l}\text { Surgeon } \\
\text { Number }\end{array}$ & $\begin{array}{l}\text { follow-up } \\
\text { time }\end{array}$ & Cases DAA:PA & ages DAA:PA & $\begin{array}{l}\text { male/female } \\
\text { DAA:PA }\end{array}$ & $\begin{array}{l}\text { BMI DAA:PA } \\
\text { learning } \\
\text { cases }\end{array}$ \\
\hline Barrett & 2013 & RCT & 1 & 12 months & $43: 44$ & $61.4 \pm 9.2: 63.2 \pm 7.7$ & $29 / 14: 19 / 25$ & $30.7 \pm 5.4: 29.1 \pm 5.0$ & $\mathrm{NO}$ \\
Cheng & 2016 & RCT & 2 & 12 weeks & $35: 37$ & $59: 62.5$ & $15 / 20: 18 / 20$ & 27.728 .3 & $\mathrm{NO}$ \\
Christensen & 2015 & RCT & 1 & 6 weeks & $28: 23$ & $64.3 \pm 9.1: 65.2 \pm 9.1$ & $13 / 15: 11 / 12$ & $31.1 \pm 5.1: 30.4 \pm 3.6$ & $\mathrm{NO}$ \\
Luo & 2016 & RCT & 1 & 16 months & $52: 52$ & $61.5 \pm 7.2: 63.7 \pm 6.8$ & $17 / 35: 22 / 30$ & $22.7 \pm 4.4: 24.2 \pm 3.7$ & $\mathrm{NO}$ \\
Rykov & 2017 & RCT & 3 & 6 weeks & $23: 23$ & $62.8 \pm 6.1: 60.2 \pm 8.1$ & $8 / 15: 11 / 12$ & $29.0 \pm 5.6: 29.3 \pm 4.8$ & $\mathrm{NO}$ \\
Zhang & 2006 & RCT & Not clear & 30 months & $60: 60$ & $61: 62.5$ & $25 / 35: 28 / 32$ & not stated & NO \\
Zhao & 2017 & RCT & Not clear & 6 months & $60: 60$ & $64.88 \pm 12.13: 62.18 \pm 14.72$ & $24 / 36: 26 / 34$ & $24.3 \pm 53.1: 25.58 \pm 2.83$ & $\mathrm{NO}$ \\
\hline
\end{tabular}




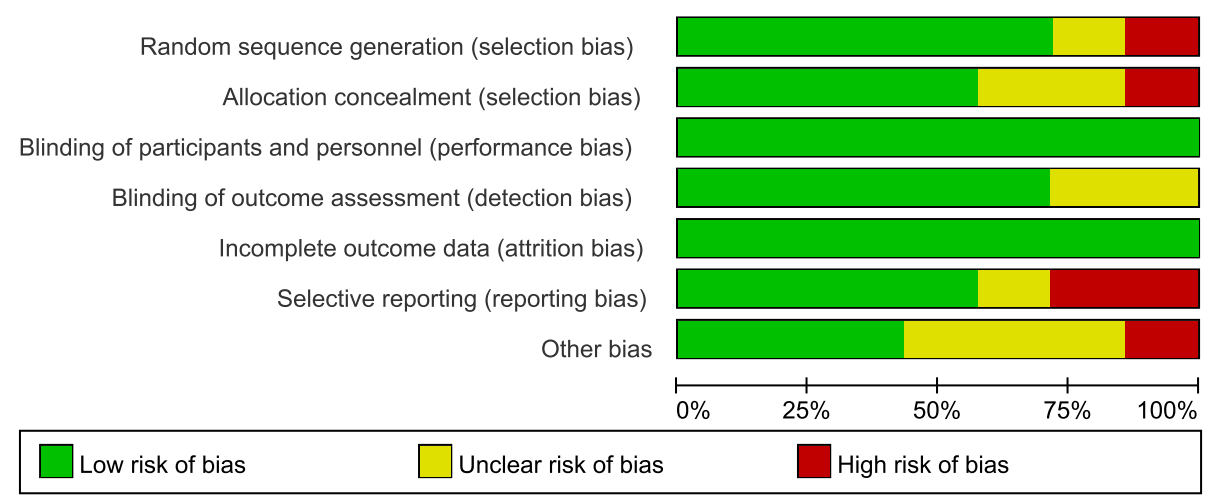

Fig. 2 Risk of bias graph: a summary of the authors' decisions about each risk of bias item presented as percentages across all included studies

\section{Risk of bias in individual studies}

Two authors assessed the risk of bias for each article by the Cochrane Bias risk assessment tool. Disagreements were resolved by discussion with a senior researcher. We determined whether each study had a low, high or unclear risk of bias in each domain.

\section{Outcome measures and statistical analysis}

We conducted this study using Review Manager software 5.3. All the data were extracted into Excel first and then divided into categorical variables and continuous variables. Categorical variables (transfusion rates, complications (such as dislocation, fracture, LCNT neuropraxia, DVT and overall complication)) were expressed as odds ratios (ORs) with $95 \%$ confidence intervals CIs. Continuous variables (length of incision, surgery time, length of stay, blood loss, acetabular inclination, acetabular anteversion, the VAS score at 1 day, 2 days, and 12 months postoperatively and the Harris hip score at 6 weeks, 3 months, 6 months, and 12 months postoperatively) were expressed as the mean differences (MD) with $95 \%$ CIs. We used a fixed effects model when there was no statistical heterogeneity among the studies $(p>$ $\left.0.1, \mathrm{I}^{2}<50 \%\right)$ and a random effects model when heterogeneity existed $\left(p<0.1, \mathrm{I}^{2}>50 \%\right)$. Otherwise, a descriptive analysis was used. The results of the meta-analysis were shown in forest plots; we considered $p<0.05$ to indicate a statistically significant difference.

\section{Results}

\section{Study selection}

We initially identified 969 studies and included 7 randomized controlled trials with 600 participants in the meta-analysis after screening for eligibility [18-20, 2831]. The PRISMA study flow diagram was shown in Fig. 1.

\section{Study characteristics}

A total of 7 randomized controlled trials with 600 participants were included. One study showed statistically significant differences between genders [28], and one study did not provide BMI data [19]. None of the studies

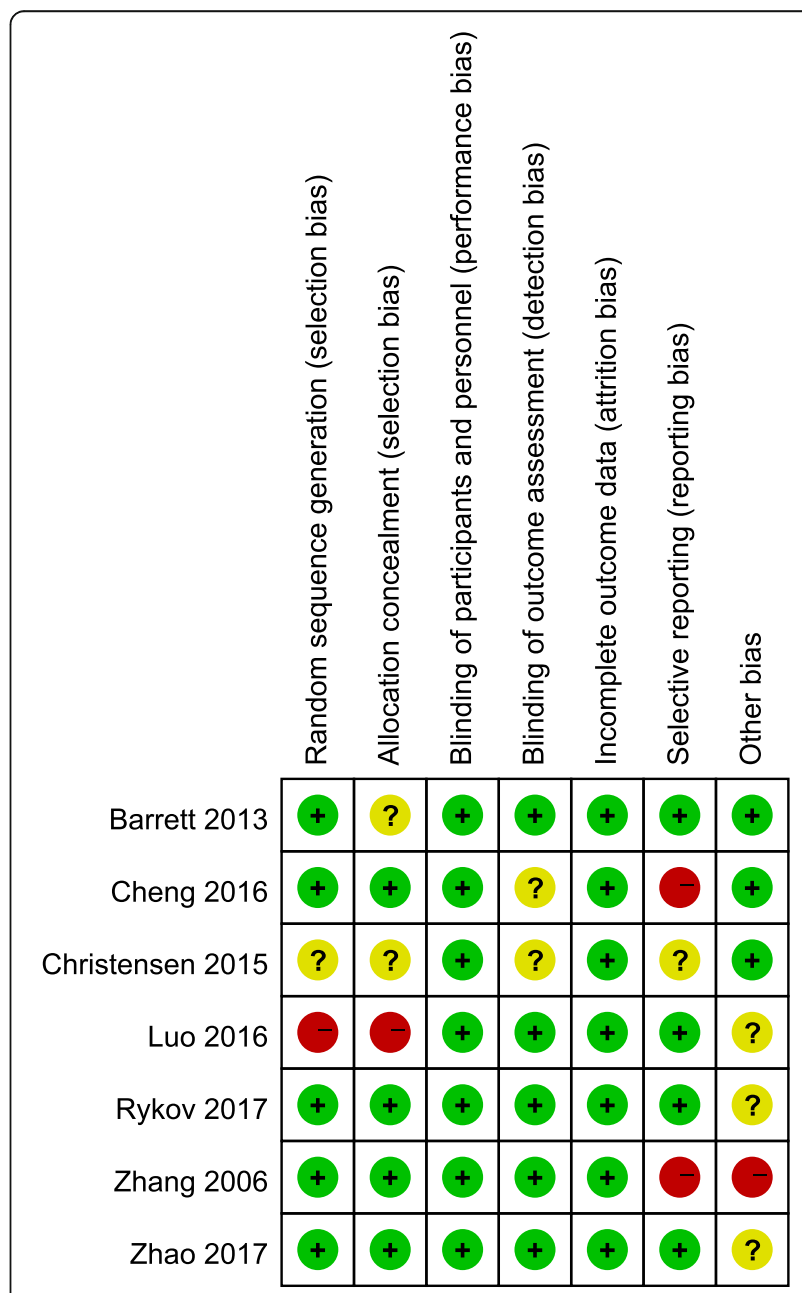

Fig. 3 Risk of bias summary: a summary of the authors' decisions about each risk of bias item for each included study 


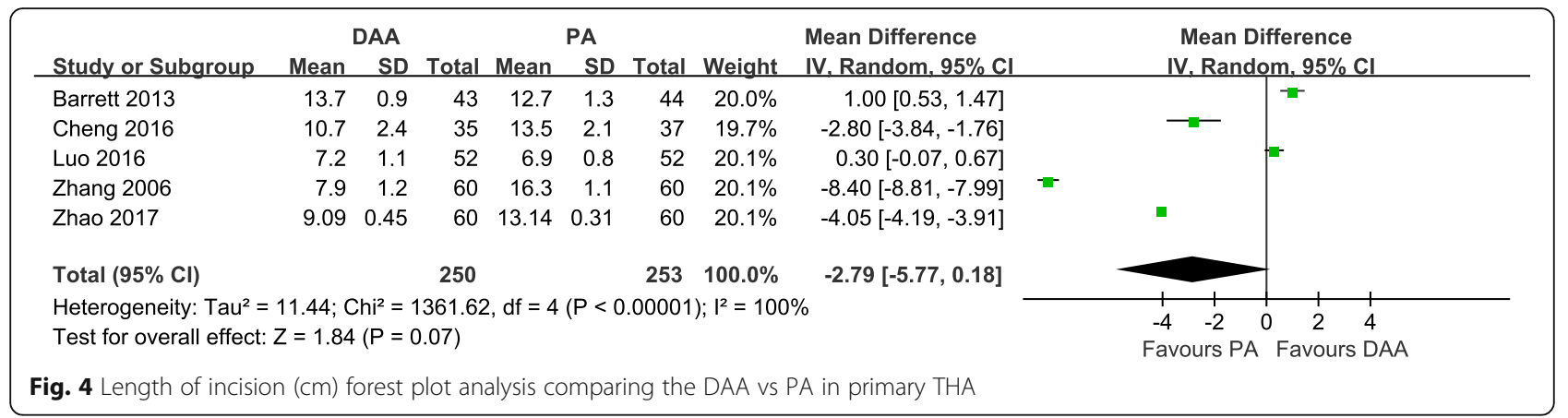

included learning cases. The demographic characteristics of the patients were shown in Table 1 .

\section{Risk of bias}

All the studies included in the meta-analysis were randomized controlled trials of high quality. It is difficult to blind the doctors performing surgeries to the patient groups, but we think that the absence of blinding did not contribute to detection bias, at least in some outcome parameters. The risk of bias graph for each study and the risk of bias summary were shown in Figs. 2 and 3.

\section{Clinical outcomes \\ Length of the incision}

Five studies [18-20, 28, 31] with a total of 503 patients were included in the comparison of the length of the incision between the DAA and PA in primary THA. We failed to find a significant difference between the DAA group and PA group, and there was statistically significant heterogeneity among the studies $(M D=-2.79 \mathrm{~cm}$, $95 \% \mathrm{CI}-5.77$ to $0.18, p=0.07, \mathrm{I}^{2}=100 \%$, Fig. 4 ).

\section{Surgery duration}

Six studies $[18-20,28,30,31]$ with a total of 549 patients were included in the comparison of the surgery duration between the DAA and PA in primary THA. The DAA required a significantly longer surgery duration (13.74 $\mathrm{min}, 6.88$ to $20.61, p<0.0001$, Fig. 5), but there was statistically significant heterogeneity among the studies $\left(\mathrm{I}^{2}=93 \%\right)$.

\section{Blood loss}

Four studies [20, 28, 30, 31] with a total of 357 patients were included in the comparison of perioperative blood loss between the DAA and PA in primary THA. We failed to find a significant difference between the DAA group and PA group, and there was statistically significant heterogeneity among the studies $(\mathrm{MD}=58.96 \mathrm{ml}$, $95 \%$ CI -4.46 to $122.38, p=0.07, \mathrm{I}^{2}=97 \%$, Fig. 6 ).

\section{Transfusion rates}

Three studies [19, 20, 31] with a total of 344 patients were included in the comparison of the transfusion rates between the DAA and PA in primary THA. We failed to find a significant difference between the DAA group and PA group, and there was statistically significant heterogeneity among the studies $(\mathrm{OR}=0.35,95 \% \mathrm{CI} 0.04$ to 3.15, $p=0.35, \mathrm{I}^{2}=87 \%$, Fig. 7).

\section{Length of hospital stay (LOS)}

Six studies [18, 19, 28-31] with a total of 496 patients were included in the comparison of the LOS between the DAA and PA in primary THA. There was no significant difference between the DAA group and PA group in terms of the LOS (MD $=-1.52$ day, 95\% CI -3.75 to $0.71, p=0.18$, Fig. 8). There was statistically significant heterogeneity among the studies $\left(\mathrm{I}^{2}=100 \%\right)$.

\begin{tabular}{|c|c|c|c|c|c|c|c|c|c|c|c|c|}
\hline Study or Subgroup & \multicolumn{2}{|r|}{ DAA } & \multicolumn{3}{|r|}{ PA } & Total & Weight & $\begin{array}{l}\text { Mean Difference } \\
\text { IV, Random, } 95 \% \mathrm{Cl}\end{array}$ & \multicolumn{4}{|c|}{$\begin{array}{c}\text { Mean Difference } \\
\text { IV. Random, } 95 \% \mathrm{Cl}\end{array}$} \\
\hline Barrett 2013 & 84.3 & 12.4 & 43 & 60.5 & 12.4 & 44 & $16.5 \%$ & $23.80[18.59,29.01]$ & & & $-\square$ & \\
\hline Cheng 2016 & 125 & 20 & 35 & 100 & 15 & 37 & $14.5 \%$ & $25.00[16.80,33.20]$ & & & -- & \\
\hline Luo 2016 & 57.6 & 9.4 & 52 & 54.4 & 8.2 & 52 & $17.5 \%$ & $3.20[-0.19,6.59]$ & & & 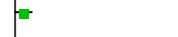 & \\
\hline Rykov 2017 & 71 & 7 & 23 & 62 & 7 & 23 & $17.1 \%$ & $9.00[4.95,13.05]$ & & & - & \\
\hline Zhang 2006 & 75 & 11.1 & 60 & 69 & 11.2 & 60 & $17.2 \%$ & $6.00[2.01,9.99]$ & & & - & \\
\hline Zhao 2017 & 83.26 & 6.69 & 60 & 65.48 & 13.32 & 60 & $17.3 \%$ & $17.78[14.01,21.55]$ & & & - & \\
\hline Total $(95 \% \mathrm{Cl})$ & & & 273 & & & 276 & $100.0 \%$ & $13.74[6.88,20.61]$ & & & & \\
\hline $\begin{array}{l}\text { Heterogeneity: } \mathrm{Tau}^{2}= \\
\text { Test for overall effect: }\end{array}$ & $\begin{array}{l}67.21 ; C \\
Z=3.93\end{array}$ & $\begin{array}{l}\mathrm{Chi}^{2}=7 \\
(\mathrm{P}<0\end{array}$ & $\begin{array}{l}74.06, d \\
0.0001)\end{array}$ & $f=5(P$ & $<0.000$ & 001); $\left.\right|^{2}$ & $=93 \%$ & & -100 & $\begin{array}{l}-50 \\
\text { Fa }\end{array}$ & $\begin{array}{lr}0 & 50 \\
A & \text { Favours DAA }\end{array}$ & 100 \\
\hline
\end{tabular}




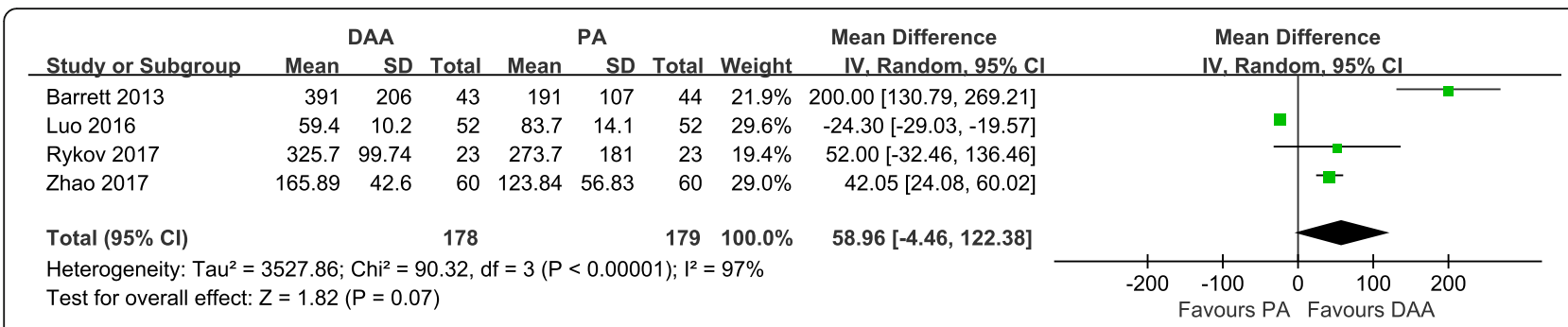

Fig. 6 Blood loss $(\mathrm{ml})$ forest plot analysis comparing the DAA vs PA in primary THA

\section{Complications}

Five studies [18-20, 28, 31] were included in the comparison of the complications between the DAA and PA in primary THA. Three studies $[18,20,28]$ reported the occurrence of postoperative dislocation. There was no significant difference between the two groups in terms of the number of cases of dislocation $(\mathrm{OR}=0.52,95 \% \mathrm{CI}$ 0.09 to $3.08, p=0.48, \mathrm{I}^{2}=0 \%$, Fig. 9). Three studies [18, $28,31]$ reported the occurrence of postoperative fractures. There was no significant difference between the two groups in terms of the number of fractures (OR = $1.45,95 \%$ CI 0.27 to $7.66, p=0.67, \mathrm{I}^{2}=0 \%$, Fig. 10). Three studies [18-20] reported the occurrence of postoperative DVT. There was no significant difference between the two groups in terms of the number of cases of DVT $\left(\mathrm{OR}=0.43,95 \% \mathrm{CI} 0.08\right.$ to $2.45, p=0.34, \mathrm{I}^{2}=0 \%$, Fig. 11). Two studies $[18,20]$ reported the occurrence of postoperative LCNT neuropraxia. There was no significant difference between the two groups in terms of the number of cases of LCNT neuropraxia (OR $=43.20,95 \%$ CI 0.70 to $2654.71, p=0.07, \mathrm{I}^{2}=74 \%$, Fig. 12). Four studies $[18-20,28]$ reported overall number of postoperative complications. There was no significant difference between the two groups in terms of the number of overall postoperative complications $(\mathrm{OR}=1.39,95 \% \mathrm{CI} 0.72$ to $2.66, p=0.32, \mathrm{I}^{2}=0 \%$, Fig. 13 ).

\section{Functional outcomes}

\section{VAS score}

Three studies [20, 28, 31] with a total of 311 patients were included in the comparison of the VAS score between the DAA and PA in primary THA. There was no significant difference between the two groups in terms of the preoperative VAS score $(\mathrm{MD}=-0.08,95 \%$ $\mathrm{CI}-0.41$ to $0.25, p=0.62, \mathrm{I}^{2}=42 \%$, Fig. 14$)$. Two studies $[28,31]$ reported the VAS score on 1 st and 2nd day postoperatively. The DAA yield a significantly higher VAS score at 1 st day postoperatively $(\mathrm{MD}=-0.65,-0.91$ to $-0.38, p<0.00001, \mathrm{I}^{2}=0 \%$, Fig. 15). The DAA showed a significantly higher VAS score at 2nd days postoperatively $(\mathrm{MD}=-0.67,-1.34$ to $-0.01, p=0.05$, $\mathrm{I}^{2}=88 \%$, Fig. 16), but there was statistically significant heterogeneity among the studies $\left(\mathrm{I}^{2}=88 \%\right)$. Two studies $[20,28]$ reported the VAS score at 12 months postoperatively. There was no significant difference between the two groups in terms of the VAS score at 12 months postoperatively $(\mathrm{MD}=-0.01,95 \% \mathrm{CI}-0.47$ to $0.50, p=$ 0.96, $\mathrm{I}^{2}=72 \%$, Fig. 17).

\section{Harris hip score (HHS)}

Five studies $[19,20,28,30,31]$ with a total of 477 patients were included in the comparison of the HHS score between the DAA and PA in primary THA. There was no significant difference between the two groups in terms of the preoperative HHS score $(\mathrm{MD}=-0.61,95 \%$ CI -2.15 to $0.93, p=0.44, \mathrm{I}^{2}=12 \%$, Fig. 18$)$. Two studies $[28,30]$ reported the HHS score at 6 weeks postoperatively. The DAA yield a significantly higher HHS score at 6 weeks postoperatively $(\mathrm{MD}=6.05,1.14$ to $10.95, p=$ $0.02, \mathrm{I}^{2}=52 \%$, Fig. 19). Three studies $[19,28,31] \mathrm{re}-$ ported the HHS score at 3 months postoperatively. There was no significant difference between the two

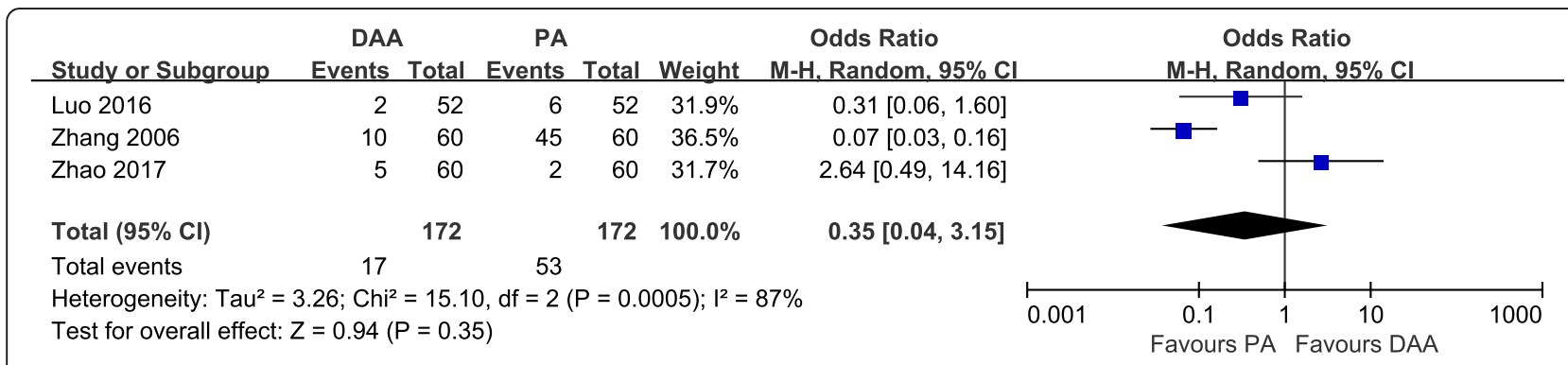

Fig. 7 Transfusion rate forest plot analysis comparing the DAA vs PA in primary THA 


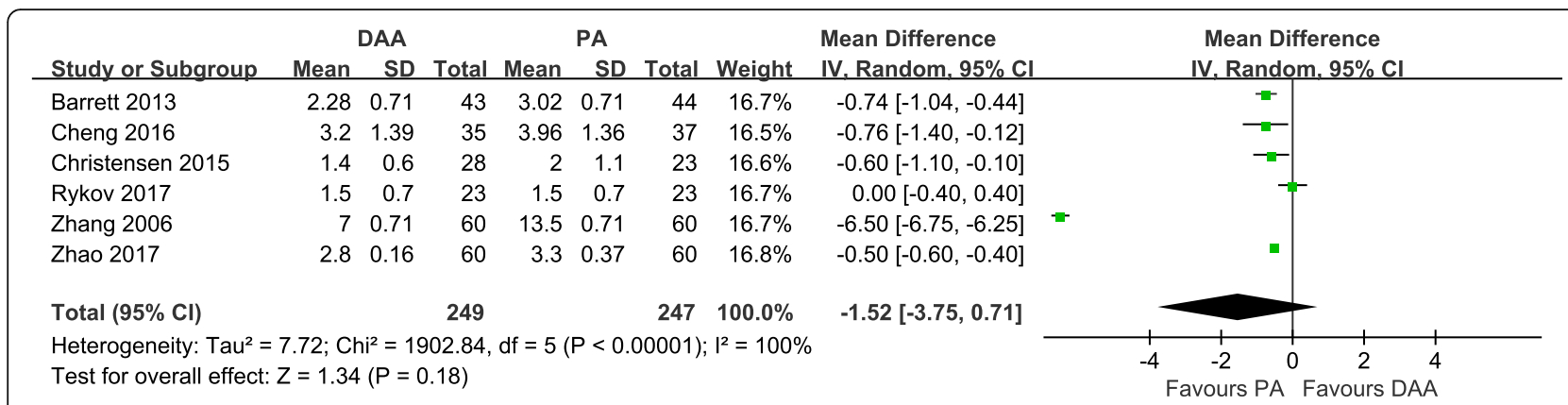

Fig. 8 Length of hospital stay forest plot analysis comparing the DAA vs PA in primary THA

groups in terms of the HHS score at 3 months postoperatively $\left(\mathrm{MD}=6.30,95 \% \mathrm{CI}-1.70\right.$ to $14.31, p=0.12, \mathrm{I}^{2}=$ $89 \%$, Fig. 20). Two studies $[28,31]$ reported the HHS score at 6 months postoperatively. There was no significant difference between the two groups in terms of the HHS score at 6 months postoperatively (MD $=0.67,95 \%$ $\mathrm{CI}-1.87$ to $3.21, p=0.60, \mathrm{I}^{2}=0 \%$, Fig. 21 ). Two studies $[20,28]$ reported the HHS score at 12 months postoperatively. There was no significant difference between the two groups in terms of the HHS score at 12 months postoperatively $(\mathrm{MD}=0.65,95 \% \mathrm{CI}-1.16$ to $2.46, p=$ $0.48, \mathrm{I}^{2}=0 \%$, Fig. 22).

\section{Radiographic outcomes}

According to the Lewinnek safe zone (anteversion angle of $15^{\circ} \pm 10^{\circ}$ and abduction angle of $40^{\circ} \pm 10^{\circ}$ ) [32], we estimated the radiographic outcomes of the DAA and PA. Five studies [18-20, 28, 31] with a total of 503 patients were included in the comparison of the radiographic outcomes between the DAA and PA in primary THA. There was no significant difference between the two groups in the postoperative anteversion angle $(\mathrm{MD}=-$ 0.01, $95 \%$ CI -4.21 to $4.20, p=1.00, \mathrm{I}^{2}=96 \%$, Fig. 23). Besides, there was no significant difference between the two groups in the postoperative abduction angle $(\mathrm{MD}=$ $1.06,95 \% \mathrm{CI}-0.95$ to $3.07, p=0.30, \mathrm{I}^{2}=82 \%$, Fig. 24$)$.

\section{Discussion}

We performed this systematic review and meta-analysis of 7 randomized controlled trials with 600 participants to compare the DAA and PA in primary THA. In the comparison of the clinical outcomes, we found that the DAA was associated with a longer surgery by a mean duration of $13.74 \mathrm{~min}$ (95\% CI 6.88 to $20.61, p<0.0001$, $\mathrm{I}^{2}=93 \%$ ). There was no significant difference between the DAA and PA groups in the length of the incision, length of hospital stay (LOS), blood loss, transfusion rates or complication rates. In the comparison of functional outcomes, the early functional outcomes were significantly better in the DAA group than in the PA group, such as the visual analogue scale (VAS) score at 1st day postoperatively (MD $=-0.65,95 \% \mathrm{CI}-0.91$ to $0.38, p<0.00001, \mathrm{I}^{2}=0 \%$ ), VAS score at 2 nd days postoperatively $(\mathrm{MD}=-0.67,95 \% \mathrm{CI}-1.34$ to $-0.01, p=$ $0.05, \mathrm{I}^{2}=88 \%$ ) and Harris Hip Score (HHS) at 6 weeks postoperatively ( $\mathrm{MD}=6.05,95 \%$ CI 1.14 to $10.95, p=$ $0.02, \mathrm{I}^{2}=52 \%$ ). There was no significant difference between the two groups regarding the late functional outcomes, such as the VAS score at 12 months postoperatively or HHS scores at 3,6 , or 12 months postoperatively. Significant differences in the radiographic outcomes were not detected. To the best of the authors' knowledge, this was the first meta-analysis of RCTs with direct evidence that comprehensively compared the clinical, functional and radiographic outcomes

\begin{tabular}{|c|c|c|c|c|c|c|c|c|c|c|}
\hline Study or Subgroup & $\begin{array}{r}\text { DAA } \\
\text { Events } \\
\end{array}$ & Total & $\begin{array}{r}\text { PA } \\
\text { Events }\end{array}$ & Total & Weight & $\begin{array}{l}\text { Odds Ratio } \\
\text { M-H, Random, } 95 \% \mathrm{Cl}\end{array}$ & & $\begin{array}{r}\text { Odds } \\
M-H, \text { Randc }\end{array}$ & Ratio & \\
\hline Barrett 2013 & 0 & 43 & 1 & 44 & $30.1 \%$ & $0.33[0.01,8.41]$ & & & & \\
\hline Cheng 2016 & 1 & 35 & 1 & 37 & $39.7 \%$ & $1.06[0.06,17.61]$ & & & & \\
\hline Luo 2016 & 0 & 52 & 1 & 52 & $30.2 \%$ & $0.33[0.01,8.21]$ & & & & \\
\hline Total $(95 \% \mathrm{Cl})$ & & 130 & & 133 & $100.0 \%$ & $0.52[0.09,3.08]$ & & & & \\
\hline Total events & 1 & & 3 & & & & & & & \\
\hline $\begin{array}{l}\text { Heterogeneity: } \mathrm{Tau}^{2}= \\
\text { Test for overall effect: }\end{array}$ & $\begin{array}{l}.00 ; \mathrm{Chi}^{2} \\
=0.71(\mathrm{P}\end{array}$ & $\begin{array}{l}=0.40, \\
=0.48\end{array}$ & $d f=2(P$ & $=0.82$ & $2) ; 1^{2}=0 \%$ & & 0.005 & $\begin{array}{c}0.1 \\
\text { Favours PA }\end{array}$ & $\begin{array}{cc}1 & 10 \\
\text { Favours DAA }\end{array}$ & 200 \\
\hline
\end{tabular}




\begin{tabular}{|c|c|c|c|c|c|c|c|c|c|c|}
\hline Study or Subgroup & $\begin{array}{c}\text { DAA } \\
\text { Events }\end{array}$ & Total & $\begin{array}{r}\text { PA } \\
\text { Events }\end{array}$ & Total & Weight & $\begin{array}{c}\text { Odds Ratio } \\
\text { M-H, Random, } 95 \% \mathrm{Cl}\end{array}$ & & $\begin{array}{r}\text { Odds } \\
M-H, \text { Rand }\end{array}$ & $\begin{array}{l}\text { Ratio } \\
\text { lom. } 95 \% \mathrm{Cl}\end{array}$ & \\
\hline Barrett 2013 & 0 & 43 & 1 & 44 & $26.7 \%$ & $0.33[0.01,8.41]$ & & -6 & & \\
\hline Cheng 2016 & 2 & 35 & 1 & 37 & $46.5 \%$ & $2.18[0.19,25.20]$ & & & & \\
\hline Zhao 2017 & 1 & 60 & 0 & 60 & $26.8 \%$ & $3.05[0.12,76.39]$ & & & & \\
\hline Total $(95 \% \mathrm{Cl})$ & & 138 & & 141 & $100.0 \%$ & $1.45[0.27,7.66]$ & & & & \\
\hline Total events & 3 & & 2 & & & & & & & \\
\hline \multicolumn{6}{|c|}{$\begin{array}{l}\text { Heterogeneity: } \text { Tau }^{2}=0.00 ; \mathrm{Chi}^{2}=1.11, \mathrm{df}=2(P=0.57) ;\left.\right|^{2}=0 \% \\
\text { Test for overall effect: } Z=0.43(P=0.67)\end{array}$} & & 0.005 & $\begin{array}{l}0.1 \\
\text { Favours PA }\end{array}$ & $\begin{array}{l}1 \\
\text { Favours DA }\end{array}$ & 200 \\
\hline
\end{tabular}

Fig. 10 Postoperative fracture rate forest plot analysis comparing the DAA vs PA in primary THA

of primary total hip arthroplasty between the DAA and PA.

In contrast to meta-analyses published in the past, our study only included RCTs and compared the clinical, functional and radiographic outcomes systematically, providing level I evidence of evidence-based medicine [33]. The meta-analysis by Miller et al [24] showed a shorter incision length, less pain experienced in the hospital, a lesser need for opioid medications and a shorter LOS in the DAA group than in the PA group. However, one study [34] in their meta-analysis compared the DAA and mini-posterior approach instead of the conventional PA, which may have increased the heterogeneity. Wang et al [25] reported a significantly shorter incision length and significantly less postoperative blood loss in the DAA group than in the PA group. They also found no significant difference in the operation time or rate of complications between the two groups. However, they included one nonrandomized study and one retrospective study in the meta-analyses, which decreased the reliability of the results. Jia et al [21] found a significantly shorter LOS and significantly longer surgery duration in the DAA group than in the PA group. The authors also included a mini-posterior approach study, which may have increased the level of heterogeneity. In another meta-analysis by Miller et al [23], the DAA was found to be associated with a lower rate of infection, dislocation, and reoperation. However, most of their studies were retrospective, which inevitably led to bias. The LCNT neuropraxia outcomes varied among the studies, and only two RCTs $[18,20]$ included in our study reported this specific complication. Some other researchers [14, 21, 34] reported different LCNT neuropraxia outcomes in non-RCTs. We believe this high level of heterogeneity may be due to the different levels of experience among the surgeons. In our study, early functional outcomes, such as the VAS score at 1st day postoperatively, VAS score at 2nd days postoperatively and HHS at 6 weeks postoperatively, were significantly better in the DAA group than in the PA group. Some other studies [21, 22, 25 ] also showed better early functional outcomes and lower pain scores in the DAA group. Our findings support this conclusion and increase the level of evidence. Due to a lack of more effective data, we failed to explore functional outcomes such as the EQ. 5D, 6MWT, WOMAC and HOOS results. In a comparison of the radiographic outcomes, Jia et al [21] also found that there were little differences in the prosthetic position between the two groups.

There were nearly no statistically significant differences in the demographic characteristics of the patients in our meta-analysis. In addition, none of the studies were learning cases, which prevented this factor from influencing the results [35]. However, there was still high heterogeneity among most outcomes. We considered this result to be mainly due to the differences among the surgeons and the hospitals in how the surgical approaches were performed. The lack of a sufficient number of RCTs may be another important reason for the high heterogeneity.

\begin{tabular}{|c|c|c|c|c|c|c|c|c|c|c|}
\hline Study or Subgroup & $\begin{array}{r}\text { DAA } \\
\text { Events }\end{array}$ & Total & $\begin{array}{r}\text { PA } \\
\text { Events }\end{array}$ & Total & Weight & $\begin{array}{c}\text { Odds Ratio } \\
\text { M-H, Random, } 95 \% \mathrm{Cl}\end{array}$ & & $\begin{array}{r}\text { Odds } \\
\text { M-H, Rando }\end{array}$ & $\begin{array}{l}\text { Ratio } \\
\text { lom, } 95 \% \mathrm{Cl}\end{array}$ & \\
\hline Cheng 2016 & 0 & 35 & 1 & 37 & $29.0 \%$ & $0.34[0.01,8.70]$ & & - & & \\
\hline Luo 2016 & 1 & 52 & 1 & 52 & $38.7 \%$ & $1.00[0.06,16.43]$ & & & & \\
\hline Zhang 2006 & 0 & 60 & 2 & 60 & $32.4 \%$ & $0.19[0.01,4.11]$ & & & & \\
\hline Total $(95 \% \mathrm{Cl})$ & & 147 & & 149 & $100.0 \%$ & $0.43[0.08,2.45]$ & & & & \\
\hline Total events & 1 & & 4 & & & & & & & \\
\hline $\begin{array}{l}\text { Heterogeneity: } \mathrm{Tau}^{2}= \\
\text { Test for overall effect: }\end{array}$ & $\begin{array}{l}0.00 ; \mathrm{Chi}^{2} \\
\mathrm{Z}=0.95(\mathrm{P}\end{array}$ & $\begin{array}{l}=0.64 \\
=0.34\end{array}$ & $\mathrm{df}=2(\mathrm{P}$ & $=0.73$ & ;) $1^{2}=0 \%$ & & 0.01 & $\begin{array}{l}0.1 \\
\text { Favours PA }\end{array}$ & $1 \begin{array}{c}10 \\
\text { Favours DAA }\end{array}$ & 100 \\
\hline
\end{tabular}




\begin{tabular}{|c|c|c|c|c|c|c|c|c|c|c|}
\hline Study or Subgroup & $\begin{array}{r}\text { DAA } \\
\text { Events } \\
\end{array}$ & Total & $\begin{array}{r}\text { PA } \\
\text { Events } \\
\end{array}$ & Total & Weight & $\begin{array}{c}\text { Odds Ratio } \\
\text { M-H, Random, } 95 \% \mathrm{Cl}\end{array}$ & & $\begin{array}{r}\text { Odds } \mathrm{H} \\
\mathrm{M}-\mathrm{H}, \text { Rando }\end{array}$ & $\begin{array}{l}\text { Ratio } \\
\text { lom, } 95 \% \mathrm{Cl}\end{array}$ & \\
\hline Cheng 2016 & 29 & 35 & 0 & 37 & $50.6 \%$ & $340.38[18.42,6289.76]$ & & & & $\longrightarrow$ \\
\hline Luo 2016 & 2 & 52 & 0 & 52 & $49.4 \%$ & $5.20[0.24,110.95]$ & & & & \\
\hline Total $(95 \% \mathrm{Cl})$ & & 87 & & 89 & $100.0 \%$ & $43.20[0.70,2654.71]$ & & & & \\
\hline Total events & 31 & & 0 & & & & & & & \\
\hline $\begin{array}{l}\text { Heterogeneity: } \mathrm{Tau}^{2}= \\
\text { Test for overall effect: }\end{array}$ & $\begin{array}{l}.51 ; \mathrm{Chi}^{2} \\
=1.79(\mathrm{P}\end{array}$ & $\begin{array}{l}=3.80, \\
=0.07\end{array}$ & df $=1(P$ & $=0.05$ & $5) ; I^{2}=74 \%$ & & 0.001 & $\begin{array}{c}0.1 \\
\text { Favours PA }\end{array}$ & $\begin{array}{l}10 \\
\text { Favours DAA }\end{array}$ & 1000 \\
\hline
\end{tabular}

\begin{tabular}{|c|c|c|c|c|c|c|c|c|c|c|}
\hline Study or Subgroup & $\begin{array}{r}\text { DAA } \\
\text { Events } \\
\end{array}$ & Total & $\begin{array}{r}\text { PA } \\
\text { Events } \\
\end{array}$ & Total & Weight & $\begin{array}{l}\text { Odds Ratio } \\
\mathrm{M}-\mathrm{H} \text {, Random, } 95 \% \mathrm{Cl}\end{array}$ & & $\begin{array}{r}\text { Odds } \mathrm{F} \\
\mathrm{M}-\mathrm{H}, \text { Rando }\end{array}$ & $\begin{array}{l}\text { Ratio } \\
\text { om, } 95 \% \mathrm{Cl}\end{array}$ & \\
\hline Barrett 2013 & 10 & 43 & 7 & 44 & $36.7 \%$ & $1.60[0.55,4.69]$ & & & t & \\
\hline Cheng 2016 & 11 & 35 & 8 & 37 & $37.7 \%$ & $1.66[0.58,4.79]$ & & & & \\
\hline Luo 2016 & 4 & 52 & 3 & 52 & $17.6 \%$ & $1.36[0.29,6.41]$ & & & & \\
\hline Zhang 2006 & 1 & 60 & 3 & 60 & $8.0 \%$ & $0.32[0.03,3.19]$ & & & & \\
\hline Total $(95 \% \mathrm{Cl})$ & & 190 & & 193 & $100.0 \%$ & $1.39[0.72,2.66]$ & & & & \\
\hline Total events & 26 & & 21 & & & & & & & \\
\hline $\begin{array}{l}\text { Heterogeneity: } \mathrm{Tau}^{2}= \\
\text { Test for overall effect: }\end{array}$ & $\begin{array}{l}0.00 ; \mathrm{Chi}^{2} \\
\mathrm{Z}=0.99(\mathrm{P}\end{array}$ & $\begin{array}{l}=1.75 \\
=0.32\end{array}$ & df $=3(P$ & $=0.63$ & $3) ; I^{2}=0 \%$ & & 0.05 & $\begin{array}{l}0.2 \\
\text { Favours PA }\end{array}$ & $\begin{array}{c}5 \\
\text { Favours DAA }\end{array}$ & 20 \\
\hline
\end{tabular}

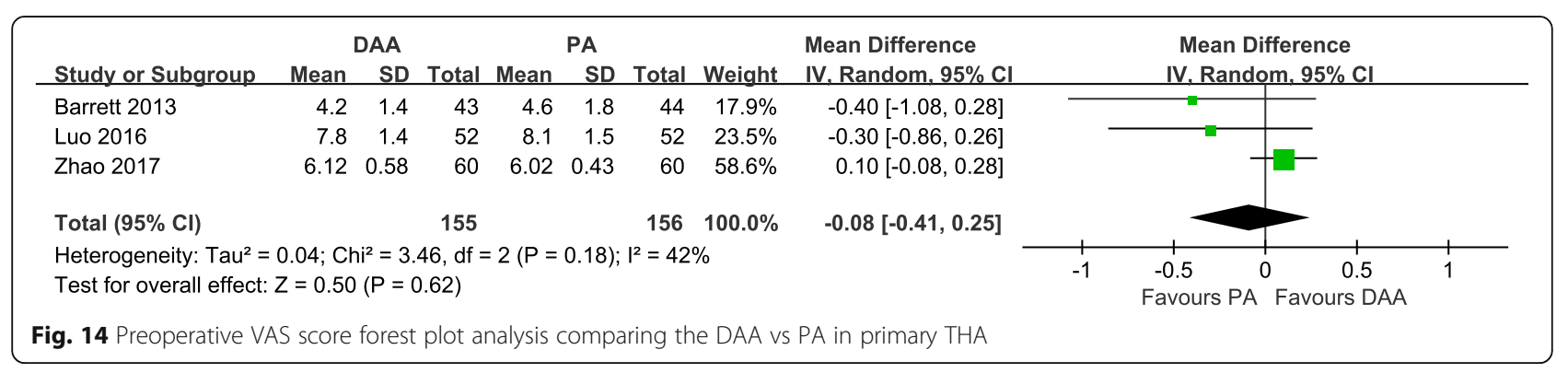

\begin{tabular}{|c|c|c|c|c|c|c|c|c|c|c|c|c|}
\hline Study or Subgroup & Mean & \multicolumn{2}{|l|}{ DAA } & Mean & \multicolumn{3}{|l|}{ PA } & $\begin{array}{l}\text { Mean Difference } \\
\text { IV. Random. } 95 \% \mathrm{Cl}\end{array}$ & \multicolumn{4}{|c|}{$\begin{array}{c}\text { Mean Difference } \\
\text { IV. Random. } 95 \% \mathrm{Cl}\end{array}$} \\
\hline Barrett 2013 & 4.2 & 1.4 & 43 & 4.6 & 1.8 & 44 & $17.9 \%$ & $-0.40[-1.08,0.28]$ & & -1 & & \\
\hline Luo 2016 & 7.8 & 1.4 & 52 & 8.1 & 1.5 & 52 & $23.5 \%$ & $-0.30[-0.86,0.26]$ & & & & \\
\hline Zhao 2017 & 6.12 & 0.58 & 60 & 6.02 & 0.43 & 60 & $58.6 \%$ & $0.10[-0.08,0.28]$ & & & & \\
\hline Total $(95 \% \mathrm{Cl})$ & & & 155 & & & 156 & $100.0 \%$ & $-0.08[-0.41,0.25]$ & & & & \\
\hline $\begin{array}{l}\text { Heterogeneity: } \mathrm{Tau}^{2}= \\
\text { Test for overall effect: }\end{array}$ & $\begin{array}{l}0.04 ; C h \\
Z=0.50\end{array}$ & $\begin{array}{l}i^{2}=3 . \\
(P=0\end{array}$ & $\begin{array}{l}6, \mathrm{df}= \\
62)\end{array}$ & $2(P=$ & $0.18)$ & $I^{2}=42^{\circ}$ & & & -1 & $\begin{array}{l}-0.5{ }^{0} \\
\text { Favours PA }\end{array}$ & $\begin{array}{c}0.5 \\
\text { Favours DAA }\end{array}$ & 1 \\
\hline
\end{tabular}




\begin{tabular}{|c|c|c|c|c|c|c|c|c|c|}
\hline \multirow[b]{2}{*}{ Study or Subgroup } & \multicolumn{3}{|c|}{ DAA } & \multicolumn{2}{|r|}{ PA } & \multirow[b]{2}{*}{ Total } & \multirow{2}{*}{\multicolumn{2}{|c|}{$\begin{array}{ll} & \text { Mean Difference } \\
\text { Weight } & \text { IV, Random, } 95 \% \mathrm{Cl}\end{array}$}} & \multirow{2}{*}{$\begin{array}{l}\text { Mean Difference } \\
\text { IV. Random, } 95 \% \mathrm{Cl}\end{array}$} \\
\hline & Mean & SD & Total & Mean & SD & & & & \\
\hline Barrett 2013 & 3.8 & 1.1 & 43 & 4.1 & 1 & 44 & $45.2 \%$ & $-0.30[-0.74,0.14]$ & \begin{tabular}{l|l}
-1 &
\end{tabular} \\
\hline Zhao 2017 & 2.11 & 0.28 & 60 & 3.09 & 0.58 & 60 & $54.8 \%$ & $-0.98[-1.14,-0.82]$ & - \\
\hline Total $(95 \% \mathrm{Cl})$ & & & 103 & & & 104 & $100.0 \%$ & $-0.67[-1.34,-0.01]$ & \\
\hline \multicolumn{8}{|c|}{$\begin{array}{l}\text { Heterogeneity: } \mathrm{Tau}^{2}=0.20 ; \mathrm{Chi}^{2}=8.00, \mathrm{df}=1(P=0.005) ; \mathrm{I}^{2}=88 \% \\
\text { Test for overall effect: } Z=1.99(P=0.05)\end{array}$} & & $\begin{array}{ccccc} & 1 & 1 & 1 & 1 \\
-1 & -0.5 & 0 & 0.5 & 1 \\
& \text { Favours } & \text { PA } & \text { Favours DAA }\end{array}$ \\
\hline
\end{tabular}

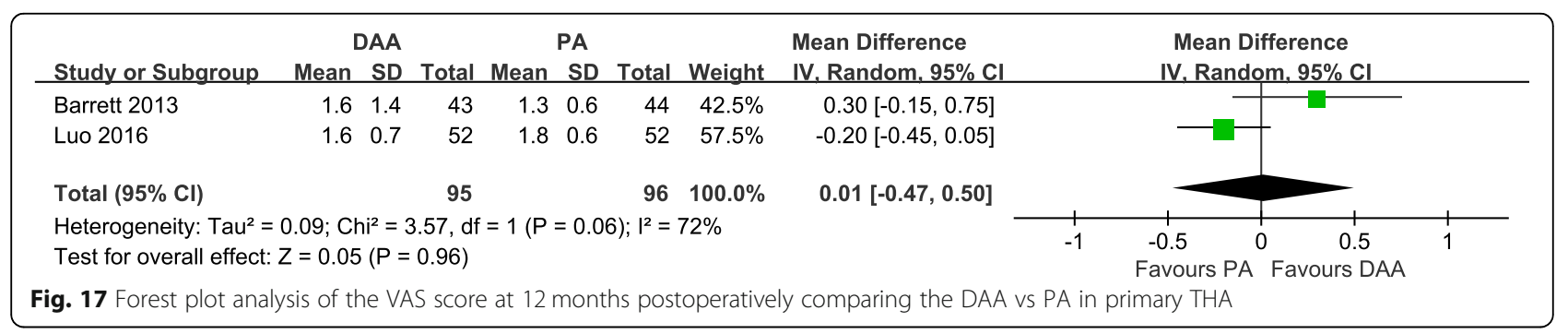

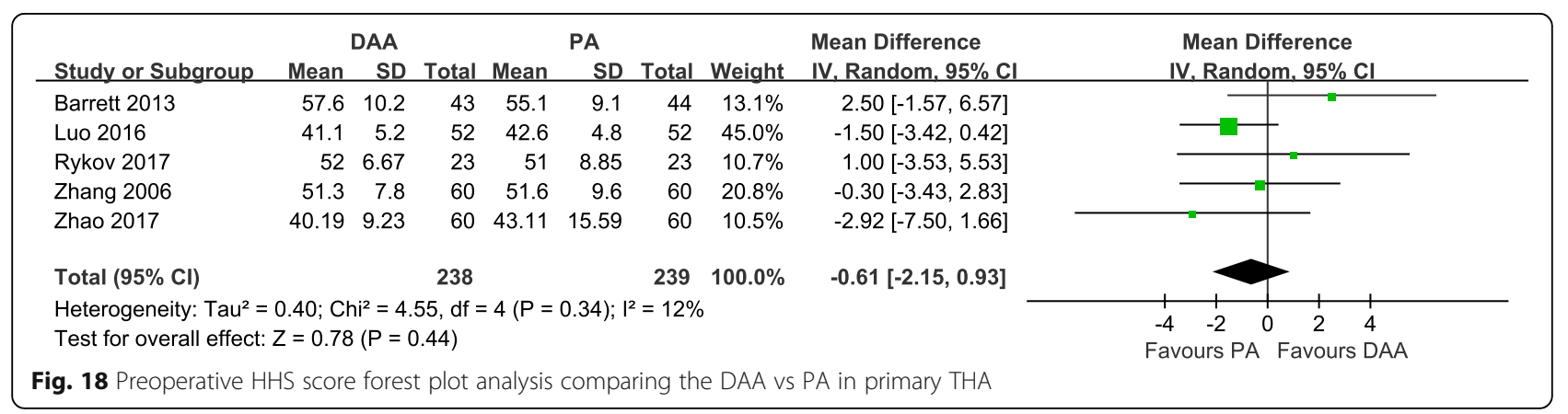

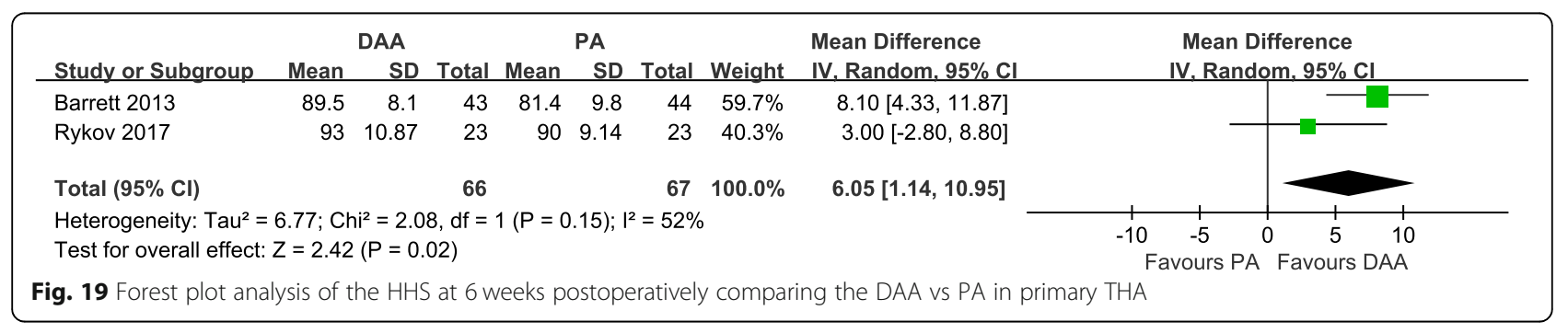

\begin{tabular}{|c|c|c|c|c|c|c|c|c|c|c|c|}
\hline \multirow[b]{2}{*}{ Study or Subgroup } & \multirow[b]{2}{*}{ Mean } & \multicolumn{3}{|l|}{ DAA } & \multicolumn{3}{|l|}{ PA } & \multirow{2}{*}{$\begin{array}{l}\text { Mean Difference } \\
\text { IV. Random. } 95 \% \mathrm{Cl}\end{array}$} & \multirow{2}{*}{\multicolumn{2}{|c|}{$\begin{array}{c}\text { Mean Difference } \\
\text { IV. Random. } 95 \% \mathrm{Cl}\end{array}$}} & \\
\hline & & SD & Total & Mean & SD & Total & Weight & & & & \\
\hline Barrett 2013 & 91.2 & 9.7 & 43 & 91.4 & 9.7 & 44 & $34.2 \%$ & $-0.20[-4.28,3.88]$ & & & \\
\hline Zhang 2006 & 91.4 & 13.5 & 60 & 78.5 & 10.8 & 60 & $33.7 \%$ & $12.90[8.53,17.27]$ & & & \\
\hline Zhao 2017 & 85.9 & 17.36 & 60 & 79.6 & 11.87 & 60 & $32.1 \%$ & $6.30[0.98,11.62]$ & & - & \\
\hline Total $(95 \% \mathrm{Cl})$ & & & 163 & & & 164 & $100.0 \%$ & $6.30[-1.70,14.31]$ & & & \\
\hline $\begin{array}{l}\text { Heterogeneity: } \mathrm{Tau}^{2}= \\
\text { Test for overall effect: }\end{array}$ & $\begin{array}{l}44.47 ; C \\
Z=1.54\end{array}$ & $\begin{array}{l}C h i^{2}=18 \\
t(P=0.1\end{array}$ & $\begin{array}{l}8.45, \mathrm{df} \\
12)\end{array}$ & $=2(P$ & $<0.0001$ & 1); $\left.\right|^{2}=\varepsilon$ & $89 \%$ & -20 & $\begin{array}{l}-10 \\
\text { Favours PA }\end{array}$ & $\begin{array}{lc}0 & 10 \\
\text { Favours DAA }\end{array}$ & 20 \\
\hline
\end{tabular}




\begin{tabular}{|c|c|c|c|c|c|c|c|c|c|}
\hline \multirow[b]{2}{*}{ Study or Subgroup } & \multirow[b]{2}{*}{ Mean } & \multicolumn{3}{|l|}{ DAA } & \multicolumn{3}{|l|}{ PA } & \multirow{2}{*}{$\begin{array}{l}\text { Mean Difference } \\
\text { IV. Random, } 95 \% \mathrm{Cl}\end{array}$} & \multirow{2}{*}{$\begin{array}{c}\text { Mean Difference } \\
\text { IV. Random, } 95 \% \mathrm{Cl}\end{array}$} \\
\hline & & SD & Total & Mean & SD & Total & Weight & & \\
\hline Barrett 2013 & 95.8 & 7.8 & 43 & 95.9 & 6.8 & 44 & $67.9 \%$ & $-0.10[-3.18,2.98]$ & \\
\hline Zhao 2017 & 92.2 & 13.25 & 60 & 89.9 & 11.74 & 60 & $32.1 \%$ & $2.30[-2.18,6.78]$ & \\
\hline \multirow{2}{*}{\multicolumn{7}{|c|}{$\begin{array}{l}\text { Total }(95 \% \mathrm{Cl}) \quad 103 \\
\text { Heterogeneity: } \text { Tau }^{2}=0.00 ; \mathrm{Chi}^{2}=0.75, \mathrm{df}=1(\mathrm{P}=0.39) ; \mathrm{I}^{2}=0 \% \\
\text { Test for overall effect: } Z=0.52(\mathrm{P}=0.60)\end{array}$}} & $100.0 \%$ & $0.67[-1.87,3.21]$ & \\
\hline & & & & & & & & & $\begin{array}{ccccc}-4 & -2 & 0 & 2 & 4 \\
& \text { Favours PA } & \text { Favours DAA }\end{array}$ \\
\hline
\end{tabular}

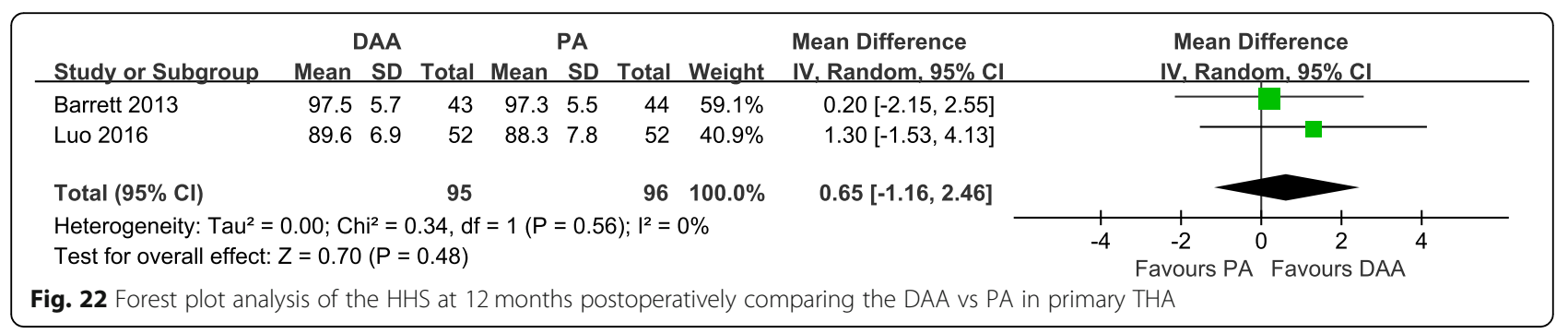

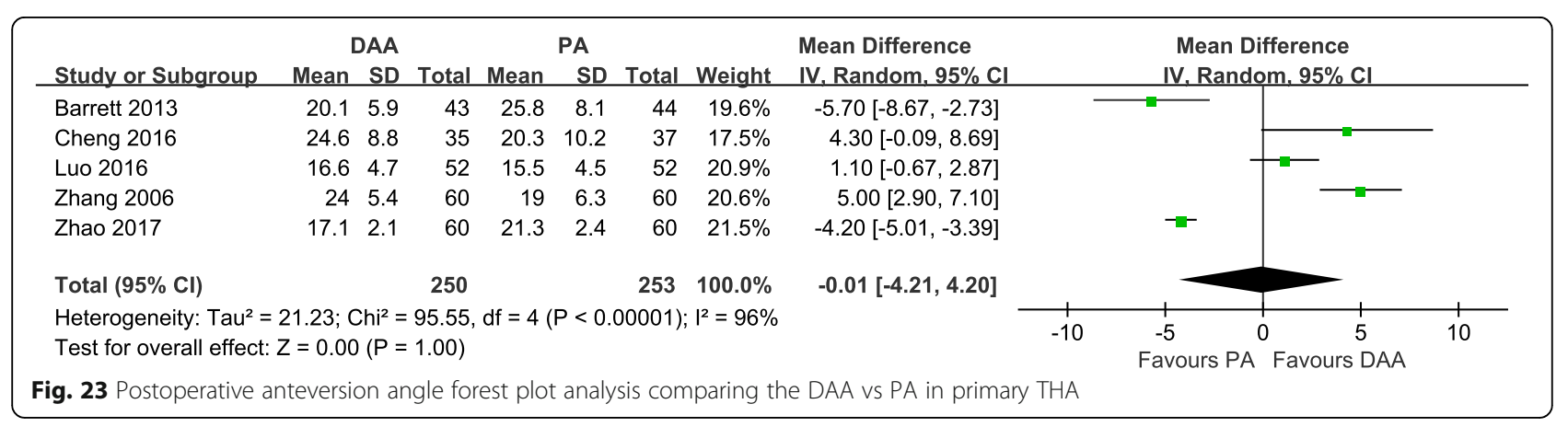

\begin{tabular}{|c|c|c|c|c|c|c|c|c|c|}
\hline Study or Subgroup & $\begin{array}{r}\text { DAA } \\
\text { Mean SD } \\
\end{array}$ & Total & Mean & $\begin{array}{l}\text { PA } \\
\text { SD }\end{array}$ & Total & Weight & $\begin{array}{l}\text { Mean Difference } \\
\text { IV, Random, } 95 \% \mathrm{Cl}\end{array}$ & \multicolumn{2}{|c|}{$\begin{array}{l}\text { Mean Difference } \\
\text { IV. Random, } 95 \% \mathrm{Cl}\end{array}$} \\
\hline Barrett 2013 & 47.16 .1 & 43 & 42.4 & 7.6 & 44 & $16.9 \%$ & $4.70[1.81,7.59]$ & \multirow{2}{*}{\multicolumn{2}{|c|}{ 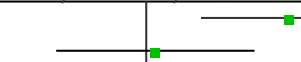 }} \\
\hline Cheng 2016 & $46.2 \quad 6.1$ & 35 & 45.9 & 8 & 37 & $15.4 \%$ & $0.30[-2.98,3.58]$ & & \\
\hline Luo 2016 & $43.3 \quad 3.7$ & 52 & 42.6 & 4.4 & 52 & $22.5 \%$ & $0.70[-0.86,2.26]$ & \multicolumn{2}{|c|}{-1} \\
\hline Zhang 2006 & $47 \quad 4.7$ & 60 & 45 & 5.9 & 60 & $21.1 \%$ & $2.00[0.09,3.91]$ & \multirow[b]{2}{*}{ 一- } & \\
\hline Zhao 2017 & $40.3 \quad 2.8$ & 60 & 41.8 & 3.4 & 60 & $24.1 \%$ & $-1.50[-2.61,-0.39]$ & & \\
\hline \multicolumn{2}{|l|}{ Total $(95 \% \mathrm{Cl})$} & \multicolumn{2}{|l|}{250} & & 253 & $100.0 \%$ & $1.06[-0.95,3.07]$ & & \\
\hline \multicolumn{7}{|c|}{$\begin{array}{l}\text { Heterogeneity: } \text { Tau }^{2}=4.03 ; \mathrm{Chi}^{2}=22.01, \mathrm{df}=4(P=0.0002) ; \mathrm{I}^{2}=82 \% \\
\text { Test for overall effect: } Z=1.03(P=0.30)\end{array}$} & & \multicolumn{2}{|c|}{$\begin{array}{ccccc}-4 & -2 & 0 & 2 & 4 \\
\text { Favours PA } & \text { Favours DAA }\end{array}$} \\
\hline
\end{tabular}


This study has several limitations. First, multiple comparisons were performed in our study, which may increase the risk of type 1 error. However, most of our test results were not significant, thereby demonstrating a low risk of type 1 error inflation. Second, the number of RCTs included in the study was insufficient, which might lead to inaccurate results. Third, some RCTs used unclear or high-risk allocation concealment and selective reporting methods, which may decrease the quality of the study. Fourth, available information about complications is insufficient. Therefore, the complication outcomes were not sufficiently reliable. Finally, we could not explore the intermediate-stage functional outcomes because of a lack of sufficient data.

\section{Conclusion}

The DAA requires a longer surgery duration than does the PA in primary total hip arthroplasty. The DAA yields improved early functional recovery compared with the PA. There was no significant difference between the two groups in terms of other clinical, complication-related, late functional or radiographic outcomes. The evidence on the superiority of the DAA is insufficient and needs to be investigated further.

\section{Abbreviations}

RCTs: Randomized controlled trials; DAA: Direct anterior approach; PA: Posterior approach; THA: Total hip arthroplasty; VAS: Visual analogue scale; MD: Mean deviation; Cl: Confidence interval; HHS: Harris hip score; LOS: Length of stay; OA: Osteoarthritis; PRISMA: Preferred reporting items for systematic reviews and meta-analyses; LCNT: Lateral cutaneous nerve of the thigh; USA: The United States of America; BMI: Body mass index; OR: Odds ratio; 6MWT: The 6-min walk test; WOMAC: The Western Ontario and McMaster Universities Osteoarthritis Index; HOOS: Hip disability, and osteoarthritis outcome score; DVT: Deep vein thrombosis

\section{Acknowledgements}

All authors have approved this study for publication.

\section{Authors' contributions}

The following authors designed the study (BS), collected the data (LBP, JFZ), analysed the data $(L B P, Y L)$, wrote the initial drafts $(L B P)$, and ensured the accuracy of the data and analysis (BS, YZ, YGW). All authors read and approved the manuscript.

\section{Funding}

This study was not supported by any funding sources.

\section{Availability of data and materials}

All data and materials are contained within the manuscript.

\section{Ethics approval and consent to participate}

Ethical approval was not necessary because this study is a review of previous RCTs, and we did not obtain any other data from patients. The need for consent to participate is not applicable.

\section{Consent for publication}

Not applicable.

\section{Competing interests}

The authors Linbo Peng, Yi Zeng, Yuangang Wu, Junfeng Zeng, Yuan Liu, and Bin Shen declare that they have no conflicts of interest.
Received: 19 January 2020 Accepted: 28 April 2020

Published online: 02 June 2020

\section{References}

1. Cross M, Smith E, Hoy D, et al. The global burden of hip and knee osteoarthritis: estimates from the global burden of disease 2010 study. Ann Rheum Dis. 2014:73:1323-30.

2. Neuprez A, Neuprez AH, Kaux J-F, et al. Total joint replacement improves pain, functional quality of life, and health utilities in patients with late-stage knee and hip osteoarthritis for up to 5 years. Clin Rheumatol. 2019. https:// doi.org/10.1007/s10067-019-04811-y.

3. Kurtz S, Mowat F, Ong K, et al. Prevalence of primary and revision total hip and knee arthroplasty in the United States from 1990 through 2002. J Bone Joint Surg Am. 2005;87:1487-97.

4. Schwartz AJ, Clarke HD, Sassoon A, et al. The Clinical and Financial Consequences of the Centers for Medicare and Medicaid Services' TwoMidnight Rule in Total Joint Arthroplasty. J Arthroplasty. 2020;35:1-6 e1.

5. Fullam J, Theodosi PG, Charity J, et al. A scoping review comparing two common surgical approaches to the hip for hemiarthroplasty. BMC Surg. 2019;19:32.

6. Ries MD. Relationship between functional anatomy of the hip and surgical approaches in Total hip Arthroplasty. Orthopedics. 2019;42:e356-63.

7. McLawhorn AS, Christ AB, Morgenstern R, et al. Prospective Evaluation of the Posterior Tissue Envelope and Anterior Capsule After Anterior Total Hip Arthroplasty. J Arthroplasty. 2019;S0883-5403(19):30928-3.

8. Meneghini RM, Pagnano MW, Trousdale RT, et al. Muscle damage during MIS total hip arthroplasty: Smith-Petersen versus posterior approach. Clin Orthop Relat Res. 2006;453:293-8.

9. Waddell J, Johnson K, Hein W, et al. Orthopaedic practice in total hip arthroplasty and total knee arthroplasty: results from the global Orthopaedic registry (GLORY). Am J Orthop (Belle Mead NJ). 2010;39:5-13.

10. Eto S, Hwang K, Huddleston Jl, et al. The direct anterior approach is associated with early revision Total hip Arthroplasty. J Arthroplast. 2017;32: 1001-5.

11. Graves SC, Dropkin BM, Keeney BJ, et al. Does surgical approach affect patient-reported function after primary THA? Clin Orthop Relat Res. 2016; 474:971-81

12. Hart A, Wyles CC, Abdel MP, et al. Thirty-day major and minor complications following Total hip Arthroplasty - a comparison of the direct anterior, lateral, and posterior approaches. J Arthroplasty. 2019;34:2681-5.

13. Martusiewicz A, Delagrammaticas D, Harold RE, et al. Anterior versus posterior approach total hip arthroplasty: patient-reported and functional outcomes in the early postoperative period. HIP Int. 2019.

14. Rodriguez JA, Deshmukh AJ, Rathod PA, et al. Does the direct anterior approach in THA offer faster rehabilitation and comparable safety to the posterior approach? Clin Orthop Relat Res. 2014;472:455-63.

15. Lin TJ, Bendich I, Ha AS, et al. A Comparison of Radiographic Outcomes After Total Hip Arthroplasty Between the Posterior Approach and Direct Anterior Approach With Intraoperative Fluoroscopy. Journal of arthroplasty. (no pagination), 2016 2016; Date of Publication: May 17.

16. Radoicic D, Zec V, Elassuity Wl, et al. Patient's perspective on direct anterior versus posterior approach total hip arthroplasty. Int Orthop. 2018;42:2771-5.

17. Kennon RE, Keggi JM, Wetmore RS, et al. Total hip arthroplasty through a minimally invasive anterior surgical approach. J Bone Joint Surg Am. 2003; 85-A(Suppl 4):39-48.

18. Cheng TE, Wallis JA, Taylor NF, et al. A prospective randomized clinical trial in Total hip Arthroplasty-comparing early results between the direct anterior approach and the posterior approach. J Arthroplast. 2017;32:883-90.

19. X-I Z, Wang Q, Jiang $Y$, et al. Minimally invasive total hip arthroplasty with anterior incision. Zhonghua Wai Ke Za Zhi. 2006:44:512-5.

20. Luo ZL, Chen M, Shang XF, et al. Direct anterior approach versus posterolateral approach for total hip arthroplasty in the lateral decubitus position. Zhonghua Yi Xue Za Zhi. 2016;96:2807-12.

21. Jia F, Guo B, Xu F, et al. A comparison of clinical, radiographic and surgical outcomes of total hip arthroplasty between direct anterior and posterio approaches: a systematic review and meta-analysis. Hip Int. 2019:29:584-96.

22. Kucukdurmaz F, Sukeik M, Parvizi J. A meta-analysis comparing the direct anterior with other approaches in primary total hip arthroplasty. Surgeon. 2019:17:291-9. 
23. Miller LE, Gondusky JS, Kamath AF, et al. Influence of surgical approach on complication risk in primary total hip arthroplasty. Acta Orthop. 2018;89: 289-94.

24. Miller LE, Kamath AF, Boettner F, et al. In-hospital outcomes with anterior versus posterior approaches in total hip arthroplasty: meta-analysis of randomized controlled trials. J Pain Res. 2018;11:1327-34.

25. Wang Z, Hou J-Z, Wu C-H, et al. A systematic review and meta-analysis of direct anterior approach versus posterior approach in total hip arthroplasty. J Orthop Surg Res. 2018;13:229.

26. Higgins JPT TJ, Chandler J, Cumpston M, Li T, Page MJ, Welch VA (editors). Cochrane Handbook for Systematic Reviews of Interventions version 6.0 (updated July 2019). Cochrane. Available from www.training.cochrane.org/ handbook. 2019.

27. Liberati A, Altman DG, Tetzlaff J, et al. The PRISMA statement for reporting systematic reviews and meta-analyses of studies that evaluate health care interventions: explanation and elaboration. J Clin Epidemiol. 2009;62:e1-e34.

28. Barrett WP, Turner SE, Leopold JP. Prospective randomized study of direct anterior vs postero-lateral approach for total hip arthroplasty. J Arthroplast. 2013:28:1634-8

29. Christensen CP, Jacobs CA. Comparison of patient function during the first six weeks after direct anterior or posterior Total hip Arthroplasty (THA): a randomized study. J Arthroplast. 2015;30:94-7.

30. Rykov K, Reininga IHF, Sietsma MS, et al. Posterolateral vs Direct Anterior Approach in Total Hip Arthroplasty (POLADA Trial): A Randomized Controlled Trial to Assess Differences in Serum Markers. J Arthroplasty. 2017; 32:3652-8 e1.

31. Zhao HY, Kang PD, Xia YY, et al. Comparison of early functional recovery after Total hip Arthroplasty using a direct anterior or Posterolateral approach: a randomized controlled trial. J Arthroplast. 2017;32:3421-8.

32. Tezuka T, Heckmann ND, Bodner RJ, et al. Functional safe zone is superior to the Lewinnek safe zone for Total hip Arthroplasty: why the Lewinnek safe zone is not always predictive of stability. J Arthroplast. 2019;34:3-8.

33. Kaefer M, Castagnetti M, Herbst K, et al. Evidence-based medicine III: level of evidence. J Pediatr Urol. 2019;15:407-8.

34. Taunton MJ, Mason JB, Odum SM, et al. Direct anterior total hip arthroplasty yields more rapid voluntary cessation of all walking aids: a prospective, randomized clinical trial. J Arthroplast. 2014:29:169-72.

35. Kagan RP, Greber EM, Richards SM, et al. Advantages of an anterior-based muscle-sparing approach in transitioning from a posterior approach for Total hip Arthroplasty: minimizing the learning curve. J Arthroplast. 2019;34: 2962-7.

\section{Publisher's Note}

Springer Nature remains neutral with regard to jurisdictional claims in published maps and institutional affiliations.

Ready to submit your research? Choose BMC and benefit from:

- fast, convenient online submission

- thorough peer review by experienced researchers in your field

- rapid publication on acceptance

- support for research data, including large and complex data types

- gold Open Access which fosters wider collaboration and increased citations

- maximum visibility for your research: over $100 \mathrm{M}$ website views per year

At $\mathrm{BMC}$, research is always in progress.

Learn more biomedcentral.com/submissions 